\title{
Hazard Identification and Risk Assessment (Hira) Analysis of Nanotechnology Laboratory in Universities in Indonesia
}

\author{
Mechanical Engineering Department, \\ Universitas Negeri Malang \\ No. 5 Semarang St, Malang, East Java, \\ Indonesia \\ djoko.kustono.ft@um.ac.id
}

Djoko Kustono

Poppy Puspitasari Mechanical Engineering Department, Universitas Negeri Malang No. 5 Semarang St, Malang, East Java, Indonesia

Center of Advanced Materials and Renewable Energy, Universitas Negeri Malang

No. 5 Semarang St, Malang, East Java, Indonesia

Muhammad Al Irsyad

Public Health Department, Universitas Negeri Malang

No. 5 Semarang St, Malang, East Java, Indonesia

Aisya Nursabrina

Public Health Department, Universitas Negeri Malang

No. 5 Semarang St, Malang, East Java, Indonesia

Erry Yulian Triblas Adesta Manufacturing and Materials Engineering Department, International Islamic University Malaysia P.O Box 10 Kuala Lumpur, Malaysia
The article describes a concept of health and safety to conduct research in Nanomaterial Laboratory in Two Public University in Malang, East Java, Indonesia. The utilization of nanomaterials in the world of education has been done in two universities in Malang, namely Malang State University and Brawijaya University. The nanomaterial laboratory as a means for research and development of nanomaterial science that often creates hazards and risks of work accidents for its users, but things that are often not realized. Dangers and risks of work accidents caused by the absence of standards. This research focuses on hazards and accidents in the nanomaterial laboratory using the HIRA (Hazard Identification and Risk Assessment) method, which is then followed by a variety of independent variables. The population in this study were nanomaterial researchers at two universities in Malang. Based on the results of trials between respondents 'competency expertise with the level of risk of workplace accidents in the nanomaterial laboratory obtained p-value $0.00(<0.05)$, meaning that there is a significant relationship between the respondents' scientific conservation and the level of work accident risk in the nanomaterials laboratory. Furthermore, the results of the study were also obtained between the research respondents with the level of risk of work accidents in the nanomaterial laboratory with a pvalue of 0.00 (<0.05), meaning that there was a significant correlation between the respondent's research experience and the level of work accident risk in the nanomaterial laboratory.

Keywords: Nanomaterial, Laboratory, Accident Risk, Occupational Health, Human Factors

\section{INTRODUCTION}

The nanomaterial is a material engineering structure that is at least 100 nanometer in size or less. The design in nanoscale can be utilized in various research areas such as physics, chemistry, even biology and medical. Materials in this size range can approach a long scale where specific physical or chemical interactions with the environment might occur. The possibility of the interaction might be a danger to the biological system and environment and has the potential to produce toxicity [1]. [2] in his research titled Nanomaterials and the Environment explained that the usage of nanoparticle in environmental technology and potential effect for health and the environment, both harmful and beneficial, are vital aspects to be considered before we can fully utilize the advantage of nanoparticle and ensure that there is no adverse consequence potential.

Laboratory as supporting facilities for departments and basic resource units for the development of science and education is a place that has the potential to cause danger and risk to humans and the environment. Therefore, standardization for the laboratory is needed to avoid the potential from happening. Based on the Decree of the Minister of Health Number 605/Menkes/SKNI1 year 2008 on Health Laboratory Office and Health Laboratory Center Standards [3], each laboratory should have an excellent standard involving labour standards, facilities standards, infrastructure and tools, media and reagent standards, laboratory safety and health as well as recording and reporting. The hazard potential in the laboratory often goes unnoticed by the involved personnel due to the lack of assessment standard and low hazard potential learning, so it is necessary to identify the hazard level in the laboratory particularly nanomaterial laboratory [4]. The data from OSHA (Occupational Safety and Health Administration) stated that almost ten thousand accident case in a research 
laboratory in 2005, injured two out of 100 scientists. Another data mentioned that the average accident level in the academical laboratory was ten up to fifty times higher than the industrial laboratory

Based on the above description on hazard potential and toxicity in nanomaterial usage, this research aimed to (1) identified the danger and work accident risk in nanomaterial laboratory in universities in Indonesia by sampling the universities in Greater Malang, (2) discover the factors or condition with "extreme risk" for work accident, and (3) compared the work risk in the laboratories between sample universities, in this research, the State University of Malang and Brawijaya University which are the most prominent universities in Greater Malang. The risk assessment was performed using the HIRA (Hazard Identification and Risk Assessment) method. This effort aimed to minimize the hazard potential and work risk in a nanotechnology laboratory. Some similar previous studies such as [5] created the need of risk assessment in all nanomaterials to evaluate the potential of nanomaterial exposure at the workplace and other effects that might occur outside the lungs. All work activities contains several dangers that cause accidents, from high risk to low. Identification and analysis could minimize the work accident that might occur [6]. The hazard resources in laboratory consist of physical, chemical and ergonomic hazards. Work environment such as lighting conditions, temperature, air circulation and noise levels must comply with applicable standards to support activities in the laboratory [7]. HIRA (Hazard Identification and Risk Assessment) is a method or technique to identify an event or condition with risk potential through observing the hazard characteristic that might occur and evaluate the risk using risk assessment matrix. Information on the danger is obtained from the identification and description of work activities, hazard cause, and hazard classification and hazard effect [8]. Evaluation is conducted using HIRA worksheet obtained from observation. Table 1 presents the risk level in the form of "severity vs likelihood".

\section{RESEARCH METHOD}

This research used descriptive analysis with a cross-sectional approach. The cross-sectional approach is research to learn the correlation dynamic between risk and effect factors by observation or collecting the data at once at a point time approach [9]. The research duration was from November 2019 to March 2020. The samples were Nanotechnology Research Laboratory at the State University of Malang and Brawijaya University. The research instrument used the checklist that was issued by the Washington State University on Laboratory Safety Self-assessment [10] and was adopted into 50 items. The data collection used observation and questionnaire (Table 1).

Table 1: HIRA (Hazard Identification and Risk Assessment)

\begin{tabular}{c|c|c|c|c|c|c}
\hline No & $\begin{array}{c}\text { Type of ac- } \\
\text { tivity }\end{array}$ & $\begin{array}{c}\text { Potential } \\
\text { hazard }\end{array}$ & Severity & Likelihood & $\begin{array}{c}\text { Hazard Risk } \\
\text { Value }\end{array}$ & Risk Level \\
\hline & & & & & & \\
\hline & & & & & & \\
\hline
\end{tabular}

\section{RESULTS AND DISCUSSION}

Table 2 is the HIRA worksheet to show the research results of Nanotechnology Laboratory in the State University of Malang.

Table 2: HIRA Worksheet of Nanotechnology Laboratory at State University of Malang.

\begin{tabular}{|c|c|c|c|c|c|}
\hline No & $\begin{array}{l}\text { Type of activity / } \\
\text { Field Conditions }\end{array}$ & Severity & Likelihood & $\begin{array}{l}\text { Risk } \\
\text { Score }\end{array}$ & $\begin{array}{l}\text { Risk } \\
\text { Level }\end{array}$ \\
\hline 1. & There is no bulkhead between rooms in the laboratory & 2 & 3 & 6 & medium \\
\hline 2. & $\begin{array}{l}\text { The laboratory does not have a particular storage area and } \\
\text { preparation area }\end{array}$ & 2 & 3 & 6 & medium \\
\hline 4. & Practicum machines are not placed in particular areas & 4 & 4 & 16 & extreme \\
\hline 5. & There is no clear evacuation route yet & 3 & 4 & 12 & high \\
\hline 6. & Room size is not up to standard $\left(<45 \mathrm{~m}^{2}\right)$ & 3 & 2 & 6 & medium \\
\hline
\end{tabular}




\begin{tabular}{|c|c|c|c|c|c|}
\hline 7. & Machine cables have not been safely insulated & 3 & 4 & 12 & high \\
\hline 8. & Lighting from outside the room is lacking & 2 & 3 & 6 & medium \\
\hline 9. & $\begin{array}{l}\text { The absence of smoke in the room (exhaust) and lack of ven- } \\
\text { tilation in the practicum area }\end{array}$ & 2 & 4 & 8 & high \\
\hline 10. & $\begin{array}{l}\text { The position of APAR which is far from the laboratory work- } \\
\text { space and the condition of APAR that has expired }\end{array}$ & 4 & 4 & 16 & extreme \\
\hline 11. & $\begin{array}{l}\text { First aid kit position inside the cupboard and incomplete con- } \\
\text { tents }\end{array}$ & 3 & 3 & 9 & high \\
\hline 12. & $\begin{array}{l}\text { The laboratory is only equipped with one main door that } \\
\text { opens inside }\end{array}$ & 3 & 4 & 12 & high \\
\hline 13. & The unavailability of trash bins in the laboratory & 2 & 2 & 4 & low \\
\hline 14. & There are no lockers for laboratory users & 2 & 1 & 2 & low \\
\hline 15. & Overloaded storage cabinet & 3 & 2 & 6 & medium \\
\hline 16. & $\begin{array}{l}\text { There is no registration form for the use of tools and practi- } \\
\text { cum materials }\end{array}$ & 3 & 4 & 12 & High \\
\hline 17. & Not all material for practicums are MSDS & 3 & 4 & 12 & high \\
\hline 18. & $\begin{array}{l}\text { The absence of instructions for use and safety signs on each } \\
\text { machine in the laboratory }\end{array}$ & 4 & 4 & 16 & extreme \\
\hline 19. & $\begin{array}{l}\text { Material for research/experiments are stored in a special cab- } \\
\text { inet without any classification of position placement }\end{array}$ & 2 & 4 & 8 & high \\
\hline 20. & $\begin{array}{l}\text { Equipment that has been used for research/experimentation } \\
\text { is not placed in the initial position }\end{array}$ & 2 & 4 & 8 & high \\
\hline 21. & $\begin{array}{l}\text { There is no specific waste disposal site for materials or rea- } \\
\text { gents }\end{array}$ & 3 & 4 & 12 & high \\
\hline 22. & $\begin{array}{l}\text { There are no SOPs for activities involving hazardous chem- } \\
\text { icals }\end{array}$ & 3 & 4 & 12 & high \\
\hline 23. & $\begin{array}{l}\text { There are no signs or warnings for work areas that require } \\
\text { personal protective equipment }\end{array}$ & 3 & 4 & 12 & high \\
\hline 24. & $\begin{array}{l}\text { There are no OHS posters and signs (safety sign) in the la- } \\
\text { boratory }\end{array}$ & 3 & 3 & 9 & high \\
\hline 25. & Conduct research/experiments without using PPE & 3 & 5 & 15 & extreme \\
\hline 26. & Practice doing a practicum in an unergonomic position & 3 & 3 & 9 & high \\
\hline 27. & $\begin{array}{l}\text { Clean up lab material spills with a regular cloth and without } \\
\text { special PPE }\end{array}$ & 3 & 4 & 12 & high \\
\hline 28. & $\begin{array}{l}\text { There is no laboratory assistant in the nanomaterial labora- } \\
\text { tory }\end{array}$ & 3 & 2 & 6 & medium \\
\hline 29. & Unused items are not placed in a particular storage area & 2 & 3 & 6 & medium \\
\hline 30. & $\begin{array}{l}\text { There are no special shoe racks and sandals that are only used } \\
\text { when in the laboratory }\end{array}$ & 2 & 1 & 2 & low \\
\hline
\end{tabular}

From Table 2, it can be seen that the State University of Malang Nanotechnology Laboratory has five items with Extreme Risk Level (Level 15 to 20 in HIRA score) and fifteen items that show High-Risk Level (Level 9 to 14 in HIRA score). In comparison, other items have low to medium score (Level 1 to 9 in HIRA score). The extreme risk condition involved (1) nanomaterial storage, (2) condition and placement of the research machines/devices, (3) condition and placement of Light Fire Extinguisher, (4) device/material utilization procedure, and (5) discipline in using Personal Protective Equipment during the activities in the Nanotechnology Laboratory. Meanwhile, Table 3 displays the Nanotechnology Laboratory at Brawijaya University. Table 3 presents that the Nanotechnology Laboratory at the Brawijaya University has seven items with Extreme Risk Level (Level 15 to 20 in HIRA score) and twelve items with High-Risk Level (Level 9 to 14 HIRA score). 
Other items have low to medium level (Level 1 to 9 HIRA score). The extreme condition involving (1) untidy cable, (2) only one exit door, (3) MSDS material and reagent are unavailable, (4) Incomplete instructions for using tools and machines, (5) discipline in using Personal Protective Equipment during the activities in the Nanotechnology Laboratory, (6) the number and placement of Light Fire Extinguisher were not appropriate, and (7) incomplete (or unavailable) SOP for each activity. The high-risk condition is twelve while the rest were in medium and low-risk condition. Based on this research, the condition of nanotechnology laboratories in the public universities were a cause of concern. The researchers, laboratory assistant, and the officials showed little attention to the laboratory that could cause a work accident. Comparing the risk level, Brawijaya University had a higher extreme risk level compared to the State University of Malang.

Table 3: HIRA Worksheet of Nanotechnology Laboratory at Brawijaya University.

\begin{tabular}{|c|c|c|c|c|c|}
\hline No & $\begin{array}{l}\text { Type of activity / } \\
\text { Field Conditions } \\
\end{array}$ & Severity & Likelihood & $\begin{array}{l}\text { Risk } \\
\text { Score }\end{array}$ & $\begin{array}{c}\text { Risk } \\
\text { Level }\end{array}$ \\
\hline 1. & Lighting from outside the room is less than the maximum & 2 & 3 & 6 & medium \\
\hline 2. & Lighting in the laboratory is not evenly distributed & 3 & 3 & 9 & high \\
\hline 3. & Machine cables have not been safely insulated & 4 & 4 & 12 & Extreme \\
\hline 4. & The ventilation system is still lacking & 2 & 4 & 8 & high \\
\hline 5. & There is no exhaust or smoke in the practicum room & 3 & 4 & 12 & high \\
\hline 6. & $\begin{array}{l}\text { The laboratory mediumly equipped with one main door that } \\
\text { opens inside }\end{array}$ & 5 & 3 & 15 & Extreme \\
\hline 7. & The unavailability of rubbish bins in the practicum area & 2 & 3 & 6 & low \\
\hline 8. & Storage space has less area & 3 & 2 & 6 & medium \\
\hline 9. & Not all materials and reagents for the practicum have MSDS & 4 & 4 & 16 & Extreme \\
\hline 10. & The absence of instructions for use on specific machines & 4 & 4 & 16 & Extreme \\
\hline 11. & $\begin{array}{l}\text { There is no temporary shelter for waste equipment that has } \\
\text { been damaged }\end{array}$ & 2 & 3 & 6 & medium \\
\hline 12. & $\begin{array}{l}\text { There is no specific waste disposal site for materials or rea- } \\
\text { gents }\end{array}$ & 3 & 4 & 12 & high \\
\hline 13. & $\begin{array}{l}\text { There are no SOPs for activities involving hazardous chemi- } \\
\text { cals }\end{array}$ & 4 & 4 & 16 & Extreme \\
\hline 14. & $\begin{array}{l}\text { There are no signs or warnings for work areas that require per- } \\
\text { sonal protective equipment }\end{array}$ & 3 & 3 & 9 & high \\
\hline 15. & $\begin{array}{l}\text { There are no OHS posters and signs (safety sign) in the labor- } \\
\text { atory }\end{array}$ & 3 & 3 & 9 & high \\
\hline 16. & Not using PPE when practicum (gloves, masks, lab coats) & 3 & 5 & 15 & Extreme \\
\hline 17. & $\begin{array}{l}\text { When doing the practicum, the practitioner's body position is } \\
\text { still not ergonomic }\end{array}$ & 3 & 3 & 9 & high \\
\hline 18. & $\begin{array}{l}\text { Clean up lab material spills with a regular cloth and without } \\
\text { special PPE }\end{array}$ & 3 & 4 & 12 & high \\
\hline 19. & $\begin{array}{l}\text { Machines, tools and documents that are not used are still in the } \\
\text { laboratory }\end{array}$ & 2 & 3 & 6 & medium \\
\hline 20. & There is no fire extinguisher in the practicum area & 4 & 3 & 12 & Extreme \\
\hline 21. & $\begin{array}{l}\text { Practicum materials are stored in a special cabinet without any } \\
\text { classification of position placement }\end{array}$ & 2 & 4 & 8 & high \\
\hline 22. & The storage rack placement is still attached to the wall & 2 & 3 & 6 & medium \\
\hline 23. & $\begin{array}{l}\text { Bottles and containers of chemicals are mixed and close to- } \\
\text { gether, and there is no information, warnings and separations } \\
\text { for hazardous chemicals }\end{array}$ & 3 & 4 & 12 & high \\
\hline 24. & There are no lockers for laboratory users & 2 & 1 & 2 & low \\
\hline
\end{tabular}




\begin{tabular}{c|l|c|c|c|c}
\hline 25. & There are no barriers between workspaces & 2 & 3 & 6 & medium \\
\hline 26. & There is no clear evacuation route & 3 & 4 & 12 & high \\
\hline 27. & $\begin{array}{l}\text { Workspace pathways are not yet free from obstacles (machin- } \\
\text { ery, materials, or the like) }\end{array}$ & 2 & 4 & 8 & high \\
\hline
\end{tabular}

\section{CONCLUSION}

The Nanotechnology at the two public Malang universities in Indonesia still showed high and extreme hazard for a work accident. The extreme risk condition involved (1) nanomaterial storage, (2) condition and placement of the research machines/devices, (3) condition and placement of Light Fire Extinguisher, (4) device/material utilization procedure, and (5) discipline in using Personal Protective Equipment during the activities in the Nanotechnology Laboratory, (1) untidy cable, (2) only one exit door, (3) MSDS material and reagent are unavailable, (7) incomplete (or unavailable) SOP for each activity. Researchers, laboratory assistants and officials in the laboratory still did not understand the dangers and risks of working in the Nanotechnology laboratory; thus, they were ignorant of work accidents risk.

\section{REFERENCES}

[1] LOWRY, G. V., GREGORY, K. B., APTE, S. C., \& LEAD, J. R. 2013. Transformation of Nanomaterials in The Environment. Environmental Science \& Technology, 46(13), 6893-6899. Retrieved from https://doi.org/10.1021/es300839e

[2] KUMAR, P., KUMAR, A., FERNANDES, T., \& AYOKO, G. A. 2011. Nanomaterials and The Environment. Jurnal of Nanomaterials, 2014. Retrieved from http://dx.doi.org/10.1155/2014/528606

[3] KEPUTUSAN MENTERI KESEHATAN No. 605 Tentang Standar Balai Laboratorium Kesehatan Dan Balai Besar Laboratorium Kesehatan. Retrieved from: https://www.scribd.com/document/350032790/KMK-No-605-Ttg-Standar-Balai-LaboratoriumKesehatan-Dan-Balai-Besar-Laboratorium-Kesehatan; On May, 15th, 2020

[4] RAHMADANI, DICKY. 2017. Analisis Potensi Risiko Bahaya Pada Laboratorium Fakultas Teknologi Industri Di Lantai 2 Dan 3 Gedung K.H Wahid Hasyim Dengan Pendekatan Hira dan Hazop. Yogyakarta: Universitas Islam Indonesia

[5] EILEEN D. KUEMPEL, CHARLES L. GERACI, PAUL A SCHULTE., Risk Assessment and Risk Management of Nanomaterials in the Workplace: Translating Research to Practic.

[6] CINDY BEAUTY SIJABAT \& SUNDAY NOYA. (2014). Application of HIRA and SPAR-H Method to Control Work Accident., Jurnal: Industrial Engineering Vol.15 (1), hal 70-79.

[7] WAWAN SULISTYO, WINARDI NUGRAHA NUGRAHA, \& ARIE BUDIANTI (2013)., Analisa Risiko Keselamatan Kerja Dengan Menggunakan Metode Hazards Identification, Risk Assessment and Risk Control (HIRAC) di Laboratorium Btpldd Ptlr Batan Serpong Banten., Jurnal: Teknik Lingkungan Vol.2 (2)

[8] SUSIHONO, W., \& AKB AR RINI, F. (2013). Penerapan Sistem Manajemen K3 dan Indentifikasi Potensi Bahaya. Jurnal Ilmiah Pengetahuan \& Penerapan Teknik Industri, 2(2). Retrieved from http://dx.doi.org/10.12928/si.v11i2.1663

[9] NOTOATMODJO, S. 2018. Metodologi Penelitian Kesehatan (Ed.3). Jakarta: Rineka Cipta

[10] WASHINGTON STATE UNIVERSITY., LABORATORY SAFETY SELF-ASSESSMENT., Retrieved from: https://s3.wp.wsu.edu/uploads/sites/2002/2014/08/Lab-self-assessment-checklist-5.pdf. On May 15 th, 2020. 